західного Полісся та прилеглих територій : зб. наук. пр. - Луцьк : РВВ «Вежа» ВДУ ім. Лесі Українки, 2004. - 163-167.

9. Основы гистологии и гистологической техники / под. ред. В. Г. Елисеева. - М. : Медицина, 1967. - 268 с.

10. Чернявских С. Д. Сезонные колебания показателей фагоцитоза эритроцитов и полиморфноядерных лейкоцитов позвоночных животных / С. Д. Чернявских, М. 3. Федорова, Е. В. Масленникова // Научные ведомости Белгородского государственного университета. - Серия «Естественные науки». 2011. - Вып. 16. - № 15. - С. 68-72.

Омельковец Ярослав. Сравнительно-морфологическое исследование эритроцитов форели ручьевой, линя и сома обыкновенного. Исследованы гематологические показатели линя (Tinca tinca L.), сома обыкновенного (Silurus glanis L.) и форели ручьевой (Salmo trutta L.), которые принадлежат к разным экологическим группам рыб и отличаются локомоторной активностью, рационом и способами добывания пищи. Приведены различия в размерах эритроцитов, их плотности, ядерно-цитоплазматическом соотношении и содержании гемоглобина в крови вышеназванных видов. Установлено, что содержание гемоглобина в крови исследуемых видов увеличивается в такой последовательности: сом обыкновенный, линь, форель ручьевая. Поскольку плотность эритроцитов в крови объектов исследования не имеет существенных отличий, то основными механизмами, которые обеспечивают рост содержания гемоглобина, является уменьшение размеров ядер эритроцитов и увеличение объема их цитоплазмы. Прогрессивным признаком можно считать увеличение относительной площади красных клеток крови за счет их удлинения.

Ключевые слова: рыбы, кровь, эритроциты, гемоглобин.

Omelkovets' Yaroslav. Comparative Morphological Study of Erythrocytes of Brook Trout, Tench And Catfish. Hematology parameters of tench (Tinca tinca L.), catfish (Silurus glanis L.) and brook trout (Salmo trutta L.), which belong to different ecological groups of fish and different locomotor activity, diet and ways of obtaining food were studied. In the article were presents differences in the size of red blood cells, their density, nuclear-cytoplasmic ratio and the content of hemoglobin in the above-mentioned species. It was found that the hemoglobin content in the blood increases in the following sequence: catfish, tench, trout brook. Since the density of red blood cells, research subjects has no significant difference, the basic mechanisms that ensure the growth of hemoglobin, red blood cells reduce the size of the nuclei and an increase in their cytoplasm. Progressive can be considered a sign of an increase in the relative area of red blood cells due to their extension.

Key words: fish, blood, red blood cells, hemoglobin.

Стаття надійшла до редколегії 19.08.2016 р.

\title{
Оксана Дунаєвська
}

\section{Особливості опорно-скоротливого апарату селезінки хребетних тварин}

На основі гістологічних досліджень установлено морфометричні особливості опорно-скоротливого апарату селезінки хребетних тварин. 3' ясовано, що в риб радіальні трабекули слаборозвинені, у жаби та ящірки вони відсутні. Опорно-скоротливий апарат займає від 3,02 до 13,64 \% відносної площі селезінки. Найбільш розвинений він у коней, овець і свиней.

Ключові слова: селезінка, капсула, трабекули, колагенові й еластичні волокна.

Постановка наукової проблеми та її значення. Селезінка - паренхіматозний орган, утворений пульпою й сполучнотканинною стромою або опорно-скоротливим апаратом (ОСА). Паренхіма та строма являють собою єдине ціле. Сполучнотканинна строма надає органу відповідної форми, забезпечує тісний контакт між клітинами пульпи, створює сприятливе біологічне середовище, у якому паренхіматозні клітини здійснюють свої функції. Вона виконує опорну, фіксуючу й амортизуючу функції $[1$, с. 57; 2; 19, с. 240-241]. У стромі галузяться кровоносні судини, що забезпечує обмін речовин, доставку судинним руслом поживних речовин і транспорт продуктів метаболізму [2; 14]. Проте на сьогодні вивчення ОСА селезінки найчастіше проводять за впливу різноманітних чинників

(С) Дунаєвська О., 2016 
[4; 7; 10; 12], а його морфометричні особливості в хребетних тварин потребують з'ясування. Особливо зараз, коли лабільність імунної системи, у тому числі селезінки, дає змогу використовувати морфологічні зміни для оцінки фізіологічного стану, моніторингу екологічного стану довкілля та створення оптимальних умов для розведення, утримання тварин, одержання 3 них безпечної продукції харчування для людини [18]. У якості таких біомаркерів виступають морфологічні показники селезінки [15].

Аналіз досліджень цієї проблеми. Сполучно-тканинна строма включає капсулу й трабекули $[1$, c. $57 ; 4$, с. $46 ; 5 ; 8 ; 9$, с. 6]. Згідно із сучасними дослідженнями до неї ще відносять ретикулярний каркас червоної пульпи та лімфоїдних вузликів і піхвові оболонки судин [2]. Найкраще вивчений ОСА в сільськогосподарських тварин. У птахів він складається з оболонки селезінки, капсули, трабекул $[10$, с. $21 ; 17$, с. 21$]$. У свійських гуски та качки площа ОСА становить $6,64 \pm 0,49$ і 6,88 $\pm 0,56 \%$

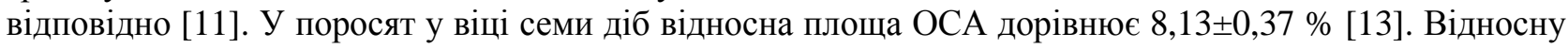
площу трабекулярного апарату великої рогатої худоби (BPX), овець і коней визначив Л. П. Го-

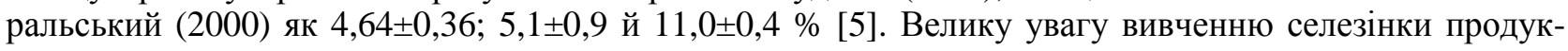
тивних тварин приділяє П. М. Гаврилін. За результатами його досліджень (у співавторстві), відносна площа ОСА ВРХ у віці 24 місяців складає 6,79\% [3].

Мета й завдання статті - виявити особливості опорно-скоротливого апарату селезінки різних класів хребетних тварин, з'ясувати морфометричні показники складників сполучнотканинної строми для розробки тест-критеріїв органа в нормі.

Матеріали й методи. Дослідження - частина наукової тематики кафедри анатомії і гістології Житомирського національного агроекологічного університету «Розвиток, морфологія та гістохімія органів тварин у нормі та при патології» (державний реєстраційний номер - 0113V000900).

Об'єкт дослідження - селезінка статевозрілих хребетних тварин обох статей у співвідношенні 1:1 у фазі морфофункціональної зрілості органа: сомів звичайних (вік - два роки), жаб озерних (вік - 2-3 роки), ящірок зелених (вік - 2-2,5 років), голубів сизих (вік - 10-14 місяців), курей домашніх породи «Полтавська глиняста» (19-20 тижнів), овець романівської породи (вік - 28 місяців), свиней великої білої породи (вік - 8-10 місяців), коней української верхової породи (вік - 4-8 років), безпородних собак (вік - 2-4 роки), ВРХ чорно-рябої породи (вік - 30 місяців) та кролів каліфорнійської породи (6-8 місяців). Тварин підібрано за принципом аналогів. Кількість відібраних зразків одного виду становила 8-32.

Для гістологічного дослідження шматочки матеріалу фіксували в 10-12 \% водному розчині нейтрального формаліну й рідині Карнуа. Парафінові зрізи фарбували гематоксиліном та еозином i за методом Ван-Гізон [6]. Морфометричні дослідження здійснювали за допомогою програми «Master of Morphology». Обробку цифрових даних виконано варіаційно-статистичними методами на персональному комп'ютері з використанням програми «Microsoft Excel». Усю експериментальну частину дослідження проведено згідно з вимогами міжнародних принципів «Свропейської конвенції щодо захисту хребетних тварин, які використовуються в експерименті та інших наукових цілях» (Страсбург, 1986 р.) та Закону України «Про захист тварин від жорстокого поводження» (№ 3446-IV від 21.02.2006 р., м. Київ).

Виклад основного матеріалу й обгрунтування отриманих результатів дослідження. У досліджених гістологічних препаратах селезінки капсула була добре розвинена, вона складалася 3 еластичних і колагенових волокон, між якими розташовувалися фібробласти й невелика кількість гладких м'язових клітин, які утворювали пучки. Капсула та трабекули утворені щільною волокнистою сполучною тканиною. Капсула ящірки, птахів складається з двох шарів - зовнішнього (еластичного) і внутрішнього (м'язового). У сполучній тканині капсули й трабекул риб більшість становили еластичні волокна. Капсула ссавців складалась із трьох шарів. Зовнішній характеризувався щільністю колагенових волокон. У середньому шарі проходили великі фібрилярні пучки, вертикально розміщені відносно зовнішнього шару. Внутрішній шар представлено пухкою сполучною тканиною. У глибині капсули більше еластичних волокон і менше колагенових. У поверховому шарі капсули колагенові волокна більш товсті. Чіткої межі між шарами немає. Найбільшу площу займає середній шар, частка якого - 31-46 \% капсули. У коней м'язові волокна утворюють окремий шар. У капсулі розміщено кровоносні й лімфатичні судини, нервові сплетіння. Отримані дані щодо будови капсули не суперечать дослідженням М. Е. Комахідзе (1971) [8], А. П. Сорокіна зі співавторами (1989) [14], Федоровської зі співавторами (2011) [1], Вишневської Т. Я. (2015) [2]. 
Товщина капсули в різних ділянках органа неоднакова, найбільше вона розвинена у воротах $\mathrm{i}$ досягає 40 мкм у риб, 66,4 мкм - у жаб, 91,3 мкм - у ящірки, 30,25 мкм - у голубів і 173,25 мкм - у курей, 672 мкм - в овець, 589,3 мкм - у свиней, 83,00 мкм - у кролів, 373,5 мкм - у ВРХ, 522,9 мкм у коней. Водночас потовщення траплялися по всій її поверхні й становили 33,2-51,6 мкм у жаб, 41,574,7 мкм - у ящірки, 18,47-24,75 мкм - у голубів та 98,36-137,26 мкм - у курей, 290,5-332 мкм - у ВРХ. Нерівномірні потовщення в окремих ділянках досягають значення 37,5 (риби), 448 (вівці), 257,3 (свині), 78,6 мкм (кролі). На вісцеральній поверхні товщина найменша - 6,56 мкм у жаб, 8,3 - у ящірки, 11,13 мкм - у голубів і 11,30 мкм - у курей, у кролів - 4,98 мкм, у коней - 33,2-132,8 мкм, у

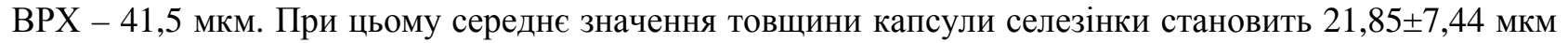

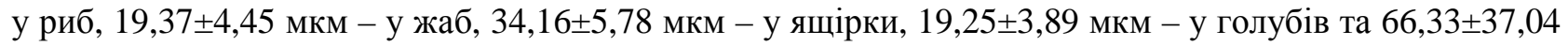

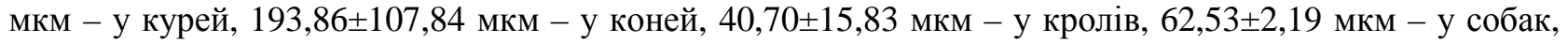
183,61 225,07 - у ВРХ. Товщина капсули свиней коливається в межах від 16,6 до 124,5 мкм. Відносна площа капсули найменша в курей і найбільша в коней (табл. 1).

Трабекули складалися зі щільної сполучної тканини, містили велику кількість колагенових й еластичних волокон, місцями - гладкі м'язові клітини. Трабекули розрізняють судинні, сполучні та радіальні. Судинні несуть у собі артерії, вени, нерви й входять у паренхіму в ділянці воріт селезінки, утворюючи трабекулярне дерево; сполучні трабекули не містять судин і відходять латерально від судинних, зміцнюючи трабекулярне дерево; радіальні трабекули відходять від внутрішньої поверхні капсули радіально вглиб до трабекулярного дерева. На мікропрепаратах селезінки сома звичайного характерною особливістю була наявність незначної кількості радіальних трабекул, які ледве помітні. Добрий розвиток отримали сполучні трабекули, які часто мали неправильну форму й були сформовані переважно пухкою сполучною тканиною. Довжина сполучних трабекул коливалась у значних межах - 37,5-162,5 мкм (середнє значення нараховувало 84,06 $\pm 39,59$ мкм), ширина 17,5-90 мкм (середнє значення - 38,75 24,01 мкм). Діаметр сполучних трабекул становив $28,75 \pm 8,75$ мкм, інколи траплялися поодинокі трабекули довжиною 90-122,5 мкм. Найбільшого розвитку досягали судинні трабекули. Їх довжина коливалась у значних межах - від 32,5 мкм до 1275 мкм, ширина - від 15 мкм до 367,5 мкм. Відношення ширини до діаметра та довжини становило 1:1,27:4,14. Відносна площа трабекулярного апарату $-3,98 \pm 2,57 \%$. У жаб капсулярні трабекули відсутні. Значно частіше траплялися судинні трабекули, яких було в 8,74 раза більше, ніж сполучних (89,73 і 10,27 \% відповідно). Судинні трабекули здебільшого розміщені в пульпі $(66,1 \%)$ та в ділянці воріт $(20,2$ \%) і підкапсулярній зоні (13,7 \%). Основна форма трабекул видовжена та овальна. Параметри судинних трабекул таких розмірів: довжина - 58,3-580,7 мкм, середне значення - 179,83 $\pm 16,34$, ширина 24,9-83,2 мкм, середнє значення - 50,72 $\pm 1,88$ мкм. У ящірки переважають судинні трабекули, капсулярні, часто не сформовані, їх довжина може сягати 188,13 мкм, ширина - до 60,87 мкм. Трабекули птахів мають переважно видовжену та овальну форму. Вони поділяються на судинні й сполучні, радіальні відсутні. Поодинокі сполучні трабекули розміщені в червоній пульпі нерівномірно та мають невеликі розміри.

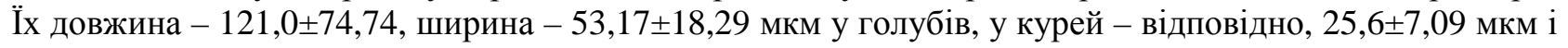
19,81 66,13 мкм. Найкраще розвинена мережа судинних трабекул. У них виявлялись артеріоли та венули. Їх довжина у голубів - 130,63 $\pm 61,77$ мкм, ширина $-50,88 \pm 9,36$ мкм, у курей - відповідно, $232,65 \pm 59,51$ мкм і 77,18 $\pm 21,79$ мкм. Частка судинних трабекул становила 89,03 \% у голубів та 74,68 \% у курей. У всіх трабекулах пучки міоцитів розвинені слабо. У ссавців кількість трабекул, які безпосередньо відходять від капсули, значно менша, ніж таких, які містяться всередині органа. У місцях відгалуження трабекул від капсули може утворюватися так званий трикутник із розширеною основою. Інколи трабекули, що відходять із протилежних сторін капсули селезінки, з'єднуються між собою й утворюють сітчастий каркас. Діаметр сполучних трабекул овець - у межах 56-508 мкм, інколи трапляються поодинокі трабекули довжиною 1288 мкм. Більшість їх має видовжену форму. Ширина коливається в значно менших межах (64-560 мкм). Судинні трабекули досягають довжини 1246 мкм, радіальні (або капсулярні) добре розвинені, розміщені вздовж усього периметра капсули, ї довжина - 700-2044 мкм. Відносна площа трабекулярного апарату в овець становила 8,7 \% (див. табл. 1). Довжина сполучних трабекул свиней - у межах 91,3-954,5 мкм, інколи - 1261,6 мкм. Переважає видовжена форма трабекул, ширина яких - 24,9-99,6 мкм. Діаметр округлих трабекул становив 33,2-99,6 мкм. Радіальні трабекули добре розвинені, розміщені вздовж усього периметра 
капсули, їх довжина нерідко становить близько 1402,7 мкм. У кролів радіальні трабекули нечисленні,

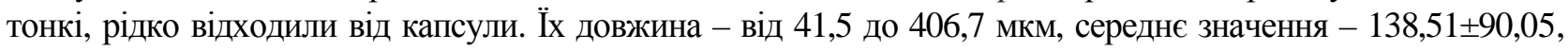

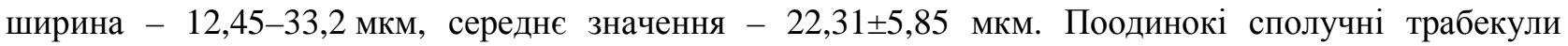
розміщувалися в червоній пульпі нерівномірно та мали невеликі розміри. За параметрами схожі на

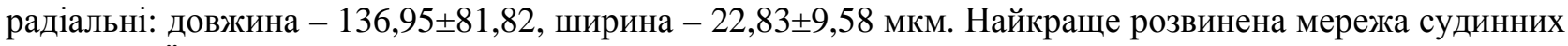
трабекул. Їх довжина - 111,46 $\pm 50,36$ мкм, ширина $-20,39 \pm 3,94$. У всіх трабекулах пучки міоцитів

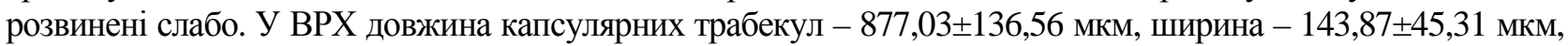

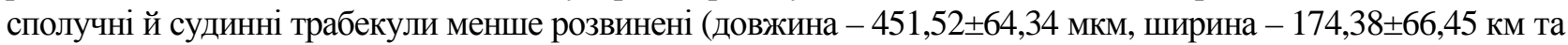
$682,44 \pm 51,93$ і 199,2 $\pm 21,51$ відповідно). У свиней довжина сполучних трабекул перебуває в межах 91,3-954,5 мкм, інколи траплялися поодинокі трабекули довжиною 1261,6 мкм. Більшість трабекул мала видовжену форму, ширина коливається незначно (24,9-99,6 мкм). Діаметр округлих трабекул 33,2-99,6 мкм. Радіальні трабекули добре розвинені, містилися вздовж усього периметра капсули, їх довжина - 1402,7 мкм. Трабекулярний апарат складав 71,16 \% від загальної площі опорноскоротливого апарату, а співвідношення капсули й трабекул - 1:2,47. У коней капсулярні трабекули добре розвинені, їх довжина - від 390,1 до 2548,1 мкм. Діаметр сполучних трабекул становив $93,38 \pm 49,00$ мкм. Судинні трабекули можна умовно поділити на малі (довжина - 330,49 166,56 мкм)

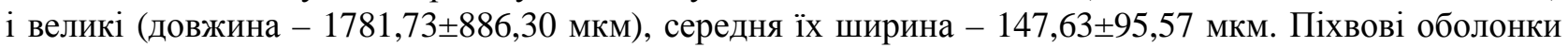
судин найбільш виражені у великих судинах, їх товщина нерідко дорівнювала товщині судинної

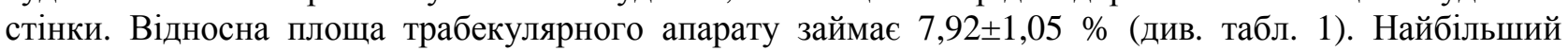
розвиток трабекулярний апарат отримав в овець, найменший - у жаб (див. табл. 1).

Таблиия 1

Відносна площа опорно-скоротливого апарату селезінки тварин, \%

\begin{tabular}{|c|c|c|c|}
\hline Вид тварини & Капсула & Трабекула & Усього \\
\hline Риба & $3,06 \pm 0,32$ & $3,98 \pm 2,57$ & $7,04 \pm 0,65$ \\
\hline Жаба & $3,71 \pm 0,85$ & $1,69 \pm 0,75$ & $5,39 \pm 0,07$ \\
\hline Ящірка & $2,11 \pm 0,86$ & $3,16 \pm 0,81$ & $5,27 \pm 0,73$ \\
\hline Голуб & $2,84 \pm 0,61$ & $6,37 \pm 1,51$ & $9,21 \pm 3,40$ \\
\hline Курка & $0,65 \pm 0,23$ & $2,37 \pm 1,57$ & $3,02 \pm 0,95$ \\
\hline Вівці & $3,38 \pm 0,33$ & $8,7 \pm 0,48$ & $12,08 \pm 0,42$ \\
\hline ВРХ & $2,89 \pm 0,41$ & $5,79 \pm 0,52$ & $8,68 \pm 0,52$ \\
\hline Свині & $2,89 \pm 0,43$ & $7,13 \pm 0,2$ & $10,02 \pm 2,99$ \\
\hline Коні & $5,72 \pm 0,44$ & $7,92 \pm 1,05$ & $5,64 \pm 1,13$ \\
\hline Кролі & $3,42 \pm 1,09$ & $2,45 \pm 1,13$ & $6,62 \pm 0,26$ \\
\hline Собака & $2,46 \pm 0,73$ & $4,16 \pm 0,96$ & 9,26 \\
\hline
\end{tabular}

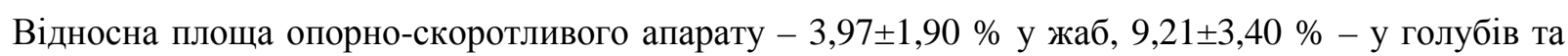

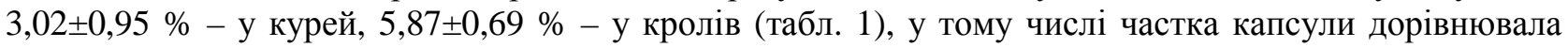
$68,83 \%, 30,84 \%, 21,52 \%$ і 58,26 \% відповідно. У коней трабекулярний апарат становив 58,07 \% від загальної кількості строми. У собак та коней у стромі добре розвинена гладка м'язова тканина, у кролів м'язові волокна трапляються рідко, що описано в праці М. Е. Комахідзе (1971) [8]. На наявність у селезінці птахів нечисленних трабекул указував В. В. Мельник [11]. Відмінність у значеннях відносних площ ОСА та його складників пояснюється регіональними, екологічними, породними особливостями, а також специфікою умов утримання та годівлі тварин.

Висновки та перспективи подальшого дослідження. Опорно-скоротливий аппарат селезінки хребетних тварин мав добре розвинені капсулу й систему трабекул. Гладка м'язова тканина в сполучно-тканинній основі селезінки найкраще розвинена в собаки, коня й найменше - у кролика. Опорно-скоротливий аппарат має найбільшу відносну площу в коней $(13,64 \pm 1,13 \%)$ і найменшу - у курей $(3,02 \pm 0,95 \%)$. Частка трабекулярного апарату в ній переважає в більшості тварин, за винятком жаб і кролів. Розрізняють судинні, сполучні й радіальні трабекули. У птахів, ящірки та жаб капсулярних трабекул не виявлено, слабкий розвиток вони отримали в риби, кролика. 


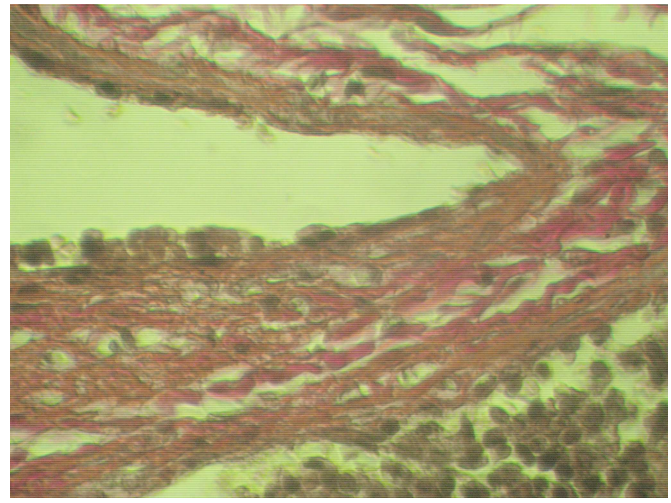

Рис. 1. Капсула селезінки коня. Ван-Гізон. $\times 80$

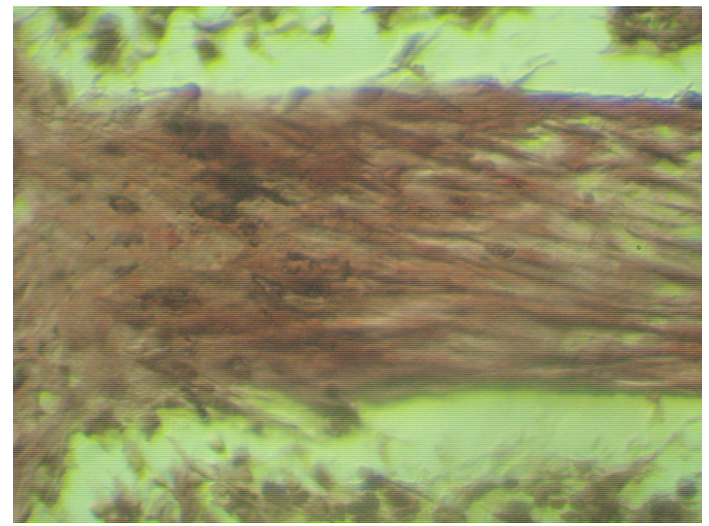

Рис. 3. Капсулярна трабекула селезінки собаки. Ван-Гізон. $\times 80$

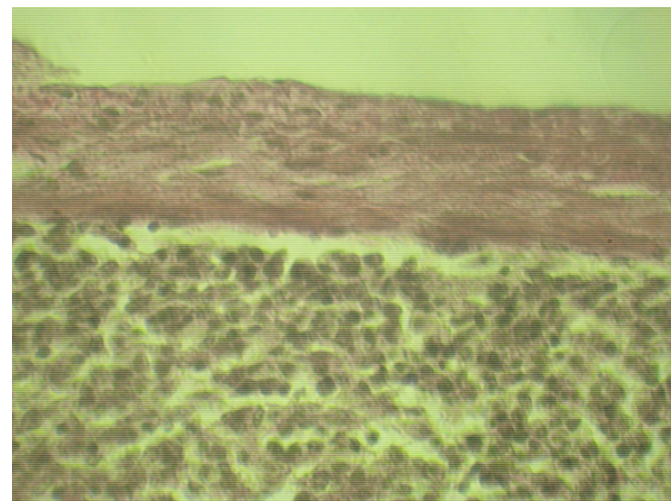

Рис. 2. Капсула селезінки овеиьь. Ван-Гізон. ×56

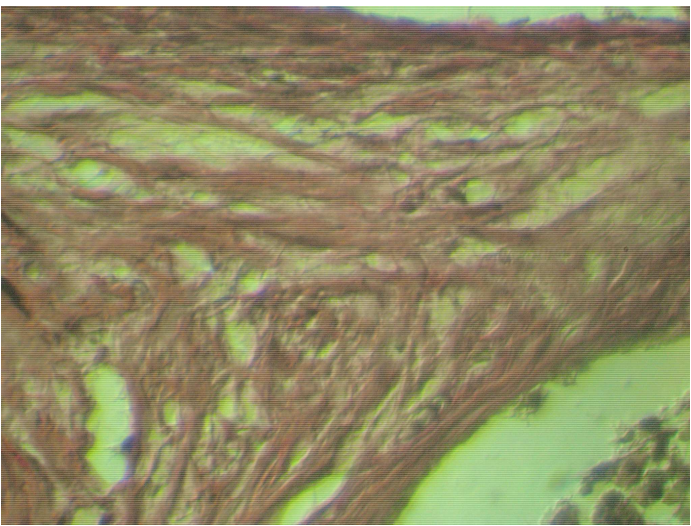

Рис. 4. Капсула й радіальна трабекула селезінки ВРХ. Ван-Гізон. $\times 80$

У подальшому планується проведення імунно- та гістохімічного дослідження селезінки хребетних тварин.

\section{Джерела та література}

1. Атлас селезёнки (видовые особенности у человека и млекопитающих животных ) : монография / Н. С. Федоровская [и др.]. - Киров : Аверс, 2011. - 134 с.

2. Вишневская Т. Я. Морфофункциональное обоснование адаптационной пластичности селезёнки животных : автореф. дис. ... д-ра биол. наук : спец. 06.02.01 «Дианостика болезней и терапия животных, патология, онкология и морфология животных» / Т. Я. Вишневская. - М., 2015. - 37 с.

3. Гаврилин П. Н. Возрастные аспекты формирования функциональных зон паренхимы селезёнки крупного рогатого скота / П. Н. Гаврилин, М. А. Лещёва, Ю. А. Филиппова // Дальневосточный аграрный вестник. - 2014. - № 2 (30). - С. 42-47.

4. Гаврилюк-Скиба Г. О. Динаміка змін мікрометричних та морфометричних показників селезінки після експериментальної термічної травми / Г. О. Гаврилюк-Скиба, К. С. Волков, 3. М. Небесна // Biomedical and biosocial antropology. - 2013. - № 20.- C. 45-48.

5. Горальський Л. П. Гістоморфологія і гістохімія окремих імуних та некровотворних органів при ретровірусних інфекціях (дослідження експериментального лейкозу рогатої худоби ті інфекційній анемії коней) : автореф. дис. ... д-ра вет. наук : спец. 16.00.02 «Патологія, онкологія і мофрологія тварин» / Л. П. Горальський. - Біла Церква, 2000. - 36 с.

6. Горальський Л. П. Основи гістологічної техніки і морфофункціональні методи досліджень у нормі та при патології : навч. посіб. / Л. П. Горальський, В. Т. Хомич, О. І. Кононський. - Житомир : Полісся, 2005. $-288 \mathrm{c}$.

7. Дунаєвська О. Ф. Вплив імуностимуляторів на імунні органи собак в умовах радіаційного забруднення : автореф. дис. ... канд. біол. наук : спец. 03.00.11 «Цитологія, клітинна біологія, гістологія» / О. Ф. Дунаєвська. - К., 2007. -22 с.

8. Комахидзе М. Э. Селезёнка / М. Э. Комахидзе. - М. : Наука, 1971. - 256 с.

9. Клименко О. М. Особливості гістологічної будови імунної системи риб : атлас мікрофотографій / О. М. Клименко, А. О. Слюсаренко, Н. М. Присяжнюк. - Біла Церква, 2010. - 32 с. 
10. Копылова С. В. Морфология селезёнки у бройлеров кросса «Смена-7» в норме и при применении «Гамавита» : автореф. дис. канд. биол. наук : спец. 06.02.01 «Диагностика болезней и терапия животных», 16.00.02 «Патология, онкология и морфология животных» / С. В. Копылова. - Саранск, $2011-27$ с.

11. Мельник В. В. Морфофункціональна характеристика лімфатичних вузлів і селезінки гусей та качок : автореф. дис. ... канд. вет. наук : спец. 16.00.02 «Патологія, онкологія і морфологія тварин» / В. В. Мельник. К., 2008. - 21 с.

12. Остапів Д. Д. Мікороструктура та вміст білків у тканинах мишей за згодовування високобілкових кормів / Д. Д. Остапів, І. М. Петрук, Ю. В. Мартин, В. В. Влізло // Наук.-техн. бюл. ін-ту біології тварин та держ. наук.-дослід. контролю ін.-ту ветпрепаратів та корм. добавок. - 2012. - Вип. 13. - № 1/2. C. 419-424.

13. Панікар I. I. Особливості морфологічної будови селезінки поросят першого тижня життя / I. I. Панікар // Ветеринарна біотехнологія. - 2015. - № 26. - С. 143-148.

14. Сорокин А. П. Клиническая морфология селезёнки / А. П. Сорокин, Н. Я. Полянкин, Я. И. Федонюк. М. : Медицина, 1989. - 160 с.

15. Спирина Е. В. Амфибии как биоиндикационная тест-система для экологической оценки водной среды обитания : автореф. дис. ... канд. биол. наук : спец. 03.00.16 «Экология» / Е. В. Спирина. - Ульяновск, 2007. $-28 \mathrm{c}$.

16. Токарев О. И. Патоморфологическия характеристика тимуса и селезёнки кур при вирусном гепатите Е : автореф. дис. ... канд. биол. наук : спец. 06.02.01 «Диагностика болезней и терапия животных, патология, онкология и морфология животных» / О. И. Токарев. - Воронеж, 2012. - 23 с.

17. Тубол О. В. Постинкубационный морфогенез селезёнки у японских перепелов : автореф. дис. ... канд. биол. наук : спец. 16.00.02 «Патология, онкология и морфология животных» / О. В. Тубол. - Саранск, $2009-24 \mathrm{c}$.

18. Фунг Н. Д. Морфобиологическая характеристика заводской молоди осетра для формирования запасов / Н. Д. Фунг, В. М. Распопов, Ю. В. Сергева // Вестник АГТУ. - Серия : «Рыбное хозяйство». - 2013. № 2. - С. 191-196.

19. Хэм А. Гистология / А. Хэм, Д. М. Кормак. - М. : Мир, 1983. - Т. 2. - 153 с.

Дунаевская Оксана. Особенности опорно-сократительного аппарата селезенки позвоночных животных. На основе гистологических исследований установлены морфометрические особенности опорно-сократительного аппарата селезенки позвоночных животных. Гладкая мышечная ткань в соединительно-тканной основе селезенки лучше всего развита у собаки, лошади и менее всего - у кролика. Опорно-сократительный аппарат занимает от 3,02 (куры) до 13,64 \% (лошади) относительной площади селезенки. Наиболее развитым он является у лошадей, овец и свиней. Трабекулярный аппарат преобладает в строме большинства животных, за исключением лягушек и кроликов. Различают сосудистые, соединительные и радиальные трабекулы. У птиц, ящерицы и лягушек капсулярных трабекул не выявляли, слабое развитие они получили у рыбы, кролика. Среднее значе-

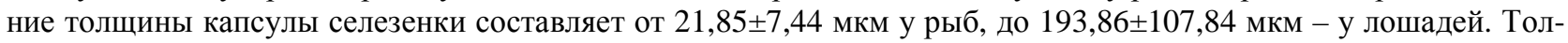
щина капсулы в разных участках органа неодинакова, больше всего она развита в воротах, по всей ее поверхности встречались утолщения, нередко превосходившие толщину капсулы в 2-3 раза. Наименее тонкая капсула - на висцеральной поверхности селезёнки.

Ключевые: селезенка, капсула, трабекулы, коллагеновые и эластичные волокна.

Oksana Dunaievska. The Features of Splenic Support-contractive Apparatus in Vertebrates. On the basis of histological research was set the morphometric characteristics of the splenic support-contractile apparatus in vertebrates. Smooth muscle tissue in the connective tissue through the spleen is best developed in dogs, horses, and least of all in the rabbit. The support-contractile apparatus takes 3,02\% (chickens) to 13,64\% (the horse) of relative spleen area. It is the most developed in horses, sheep and pigs. The trabecular apparatus prevails in the stroma of most animals except frogs and rabbits. Splenic trabeculae are distinguished vascular and radial connection. In birds, lizards and frogs capsular trabeculae are not identified; they got weak development in fish and rabbit. The average value thickness of the splenic capsule is between $21,85 \pm 7,44$ micrometers in fish to $193,86 \pm 107,84$ micrometers in horses. The thickness of the capsule varies in different parts of organ, it is the most developed in the gate, all over its surface is met a thickening, often superior to the capsule thickness in 2-3 times. The thinnest capsule is located on the visceral surface of the spleen.

Key words: spleen, capsule, trabeculae, collagen and elastic fibers.

Стаття надійшла до редколегії 15.09.2016 p. 